\title{
Inheritance of Some Quantitative Characters in Pigeonpeas (Cajanus cajan (L.) Mill sp.) ${ }^{1}$
}

Abad Morales Muñoz and Raúl Abrams

\section{INTRODUCTION}

Progress in plant breeding apparently is conditioned in a general way by the nature, magnitude, and interrelationships of genetic and nongenetic variation in various significant characters. One of the most difficult problems a plant breeder is forced to face is the identification of a desirable plant with a potentially high yield from a segregating population. Most commercial agronomic attributes are inherited quantitatively and these consequently are highly influenced by the environment in which the plants are grown. It is very difficult to judge whether observed variabilities are heritable - or due to environment. The importance of partitioning overall variability of plants into their heritable and non-heritable components is thus suggested so such information can be put to use in a plant breeding program. Knowledge of heritability may be useful in increasing the efficiency of breeding methods, because such knowledge is a measure of success in separating genotypes by selection. Association of plant characters with yield can also be of great value for the selection of desirable strains.

Pigeonpeas constitute an important part of the diet in Puerto Rico; not only because of consumer preference but also because of their high protein content. They also are of importance to the economy; the farm value of the pigeonpea crop is estimated at approximately $\$ 2$ million annually with good potential for future increase.

The present investigation was undertaken to determine heritability of quantitative characters such as date of flowering, plant height, and seed weight in different populations of pigeonpeas, and to find out the degree of association, if any, between these attributes.

\section{REVIEW OF LITERATURE}

According to Warner $(19)^{3}$, the study of hereditary and environmental components of variation began with Johannsen and Nilsson-Ehle in 1909, and East in 1916. Techniques for partitioning phenotypic variance into

1 Part of a thesis submitted by the senior author in partial fulfillment of the requirements for the M.S. degree.

${ }^{3}$ Assistant Plant Breeder and Plant Breeder, Isabela Substation, Agricultural Experiment Station, Mayagüez Campus, University of Puerto Rico, Rfo Piedras, P.R.

Numbers in parentheses refer to Literature Cited, p. 42-3. 
components were described by Mather (13). Lush (11) classified heritability percentages into two categories: (a) broad, or the ratio of genotypic to total variance, and (b) narrow, or the ratio of additive genetic to total variance. Grafius et al. (9) and Bartley and Weber (1) suggested that the magnitude of heritability value would indicate the characters for which selection would be successful and the generation when selection could be profitably practiced. Burton (4) suggested the use of both heritabilities and genetic coefficients of variation to show the progress expected from selection.

Frey and Horner (8) using the standard unit method found the heritability for heading date in 22 oat crosses to be 62,63 , and 68 percent for the $F_{2}-F_{3}, F_{8}-F_{4}$, and $F_{4}-F_{5}$ comparisons, respectively. Mahmud and Kramer (12) found heritabilities of 41 and 43 percent for height and yield, respectively, in soybeans. Fiuzat et al. (5) found heritability percentages of 86 and 90.9 percent in the $F_{2}$ generation of barley for maturity date and heading date; they therefore concluded that individual plant selection in the $F_{2}$ generation should be very effective for these characters. Swarup and Sharma (16) found heritability estimates of 37 percent for gross weight of head and 80 percent for maturity in cabbage. Wallace et al. (18) used genotypic variances and covariances to estimate the relationship between height and weight per seed with yield in oats.

The most commonly applied methods for calculating heritability percentages are parent-progeny regressions and two variance components procedures. Frey and Horner (7) concluded from their work with barley selections that (a) the heritability values as calculated by the components of variance method in the $F_{4}$ and $F_{5}$ generations are realistic and reliable; (b) the close agreement between the expected and actual gains in performance in six of the seven comparisons suggests that the gene action involved in the $F_{4}$ and $F_{5}$ generations is largely additive; (c) of the two methods of calculating heritability percentages, namely, parent-progeny regressions and components of variance, the latter gives closer agreement between predicted and actual gains in selection experiments; and (d) the parent-progeny regression method tends to under-estimate the true heritability percentages.

Robinson et al. (15) using variance components computed a selection index for corn. The analysis of variance for estimating heritability percentages was applied by Burton (B) in pearl millet, and by Robinson et al. (14) in corn.

Brim et al. (2) noted that dominance is of minor importance in selffertilizing species. In his study with soybeans the additive component of variance was indicated to be the principal component for all characters studied. Grafius et al. (9) have shown that by the fourth generation after a 
cross in self-pollinated crops, the non-additive gene effects have nearly disappeared as a cause of variability between lines.

Thomas and Kernkamp (17) found heritability ratios more convenient and useful as an aid to selection than correlation between parent and progeny.

It has been shown that the expected variance of any non-segregating population is environmental variance; thus, total variance of a segregating population would be genotypic variance plus environmental variance. Weber and Moorthy (20) used parental and $F_{1}$ values to estimate the magnitude of the environmental variation in their work with quantitative characters of soybeans.

\section{MATERIALS AND METHODS}

Three varieties and an irradiation-derived line of pigeonpeas were used as parents in five crosses as follows: P.I. 5690 (plant introduction from Trinidad) X Kaki, P.I. 5690 X Saragateado, P.I. 5690 X 526, Saragateado $X 526$ and Kaki X 526. The parents were chosen on the basis of previous data to contrast for earliness, yield, plant height, and weight per 100 seeds. Each variety was considered homozygous.

The $F_{2}, F_{3}$, and parents of each cross were planted in the field at the Isabela Substation during 1966-67 in a randomized block design with three replicates. Cross $526 \mathrm{X}$ Saragateado, however, consisted of two replicates. Planting distance was 8 feet between rows and 4 feet in the row. The $F_{2}$ and $F_{3}$ populations consisted of 200 seeds per replicate with the same spacing and row length as the non-segregating generations.

The following data were recorded for each plant in the $F_{2}, F_{3}$, and parental progenies: Flowering date, recorded as number of days from planting to first flowers on plants; plant height, measured to the nearest tenth of a foot at harvesting time; and seed weight, recorded in grams per $100 \mathrm{dry}$ seeds.

The sums of squares were calculated separately for each replication. The resulting $F_{2}$ and $F_{3}$ pooled variance contained two parts, namely, the genotypic fraction due to additive gene action including dominance and epistasis, and the fraction due to environment. The environmental variances and covariances were calculated from parental values. The $F_{2}$ and $F_{3}$ genotypic variances were determined by substracting the environmental variances from the total $F_{2}$ and $F_{3}$ variances, respectively. The same method was used in calculating the covariances. Estimates of heritability were obtained by the following formula, estimating environmental variance by the parental variance.

$$
H=\frac{\sigma_{P_{2}}^{2}-\sigma_{P}{ }^{2}}{\sigma_{P_{2}}^{2}}
$$


$H$ is the estimate of heritability, where $\sigma_{P_{2}}^{2}$ is the $F_{2}$ variance and $\sigma_{P}^{2}$ the joint mean square of parental lines. Both $\sigma_{F}^{2}$ and $\sigma_{P}^{2}$ were calculated after removing the block effect. The same procedure was used for estimating $\sigma_{R_{\mathrm{z}}}^{2}$. The estimate of genetic correlation was calculated for each pair of the characters measured by the following formula:

TABLE 1.-Mean and range for flowering date, plant height, seed weight, and number of seeds per pod of parental, $F_{2}$, and $F_{3}$ generation of five pigeonpea crosses

\begin{tabular}{|c|c|c|c|c|c|c|c|c|}
\hline \multirow{2}{*}{$\begin{array}{l}\text { Parent or } \\
\text { generation }\end{array}$} & \multicolumn{2}{|c|}{$\begin{array}{l}\text { Flowering date } \\
\text { (days) }\end{array}$} & \multicolumn{2}{|c|}{$\begin{array}{l}\text { Plant height } \\
\text { (veet) }\end{array}$} & \multicolumn{2}{|c|}{$\begin{array}{l}\text { Seed weight } \\
\text { (grams) }\end{array}$} & \multicolumn{2}{|c|}{$\begin{array}{l}\text { Average seeds per } \\
\text { pod (number) }\end{array}$} \\
\hline & Mean & Range & Mean & Range & Mean & Range & Hean & Range \\
\hline P.I. 5690 & 123.7 & $105-130$ & 4.1 & $3.4-4.7$ & 13.9 & $11-17$ & 3.6 & $2.6-4.2$ \\
\hline Kaki & 153.8 & $137-166$ & 6.5 & $5.9-7.8$ & 23.8 & $20-26$ & 3.8 & $3.8-4.4$ \\
\hline$F_{2}$ & 139.1 & $103-159$ & 5.8 & $3.8-7.8$ & 19.2 & $11-28$ & 3.7 & $2.3-5.1$ \\
\hline$F_{8}$ & 143.7 & $105-173$ & 5.9 & $3.2-8.4$ & 18.0 & $11-23$ & 3.8 & $2.0-5.1$ \\
\hline P.I. 5690 & 123.7 & $105-130$ & 4.1 & $3.4-4.7$ & 13.9 & $11-17$ & 3.6 & $2.6-4.2$ \\
\hline Saragateado & 204.2 & $186-215$ & 7.0 & $5.6-8.5$ & 17.6 & $14-21$ & 3.8 & $3.6-4.2$ \\
\hline$F_{2}$ & 152.4 & $110-190$ & 6.2 & $3.5-9.0$ & 19.2 & $12-24$ & 3.8 & $2.0-5.3$ \\
\hline$F_{8}$ & 154.1 & $110-190$ & 5.9 & $3.3-7.9$ & 18.0 & $10-24$ & 3.6 & $2.1-5.7$ \\
\hline Kaki & 153.8 & $137-166$ & 6.5 & $5.9-7.8$ & 23.8 & $20-25$ & 3.8 & $3.8-4.4$ \\
\hline 526 & 192.9 & $167-215$ & 7.0 & $5.7-8.4$ & 16.3 & $12-20$ & 3.5 & $3.1-4.8$ \\
\hline$F_{2}$ & 163.2 & $144-187$ & 7.0 & $4.0-8.8$ & 21.7 & $15-26$ & 3.7 & $3.0-4.8$ \\
\hline$F_{\mathbf{3}}$ & 156.4 & $138-187$ & 7.0 & $4.5-9.3$ & 20.4 & $12-25$ & 3.9 & $2.7-5.4$ \\
\hline P.I. 5690 & 123.7 & $105-130$ & 4.1 & $3.4-4.7$ & 13.9 & $11-17$ & 3.6 & $2.6-4.2$ \\
\hline 526 & 192.9 & $167-215$ & 7.0 & $5.7-8.4$ & 16.3 & $12-20$ & 3.5 & $3.1-4.8$ \\
\hline$F_{2}$ & 158.8 & $116-210$ & 5.8 & $3.8-7.7$ & 16.2 & $11-23$ & 3.8 & $2.1-5.5$ \\
\hline $\mathrm{F}_{8}$ & 161.1 & $110-210$ & 6.0 & $3.8-8.1$ & 15.4 & $10-23$ & 3.7 & $2.2-4.9$ \\
\hline Saragateado & 204.2 & $186-215$ & 7.0 & $5.6-8.5$ & 17.6 & $14-21$ & 3.8 & $3.6-4.2$ \\
\hline 526 & 192.9 & $167-215$ & 7.0 & $5.7-8.4$ & 16.3 & $12-20$ & 3.5 & $3.1-4.8$ \\
\hline$F_{2}$ & 192.6 & $151-224$ & 6.5 & $5.2-8.4$ & 18.3 & 12-22 & 3.8 & $2.2-4.4$ \\
\hline$F_{8}$ & 173.8 & $145-215$ & 6.5 & $4.1-8.9$ & 18.4 & $14-23$ & 3.4 & $2.3-5.1$ \\
\hline
\end{tabular}

$$
\text { Genotypic } \mathrm{r}_{x y}=\frac{\mathrm{COV}_{x y_{\rho}}}{\sqrt{\sigma_{x_{g}}^{2} \cdot \sigma_{y_{g}}^{2}}}
$$

where

$\mathrm{COV}_{x y_{\sigma}}=$ genotypic portion of the covariance between the characters $X$ and $Y$.

$\sigma_{x_{0}}^{2}$ and $\sigma_{y_{0}}^{2}=$ genotypic portion of the variance in the expression of the characters $X$ and $Y$. 
Frequency distributions were prepared for plant height, flowering date, and seed weight for both $F_{2}$ and $F_{3}$ generations together with parental means for all crosses.

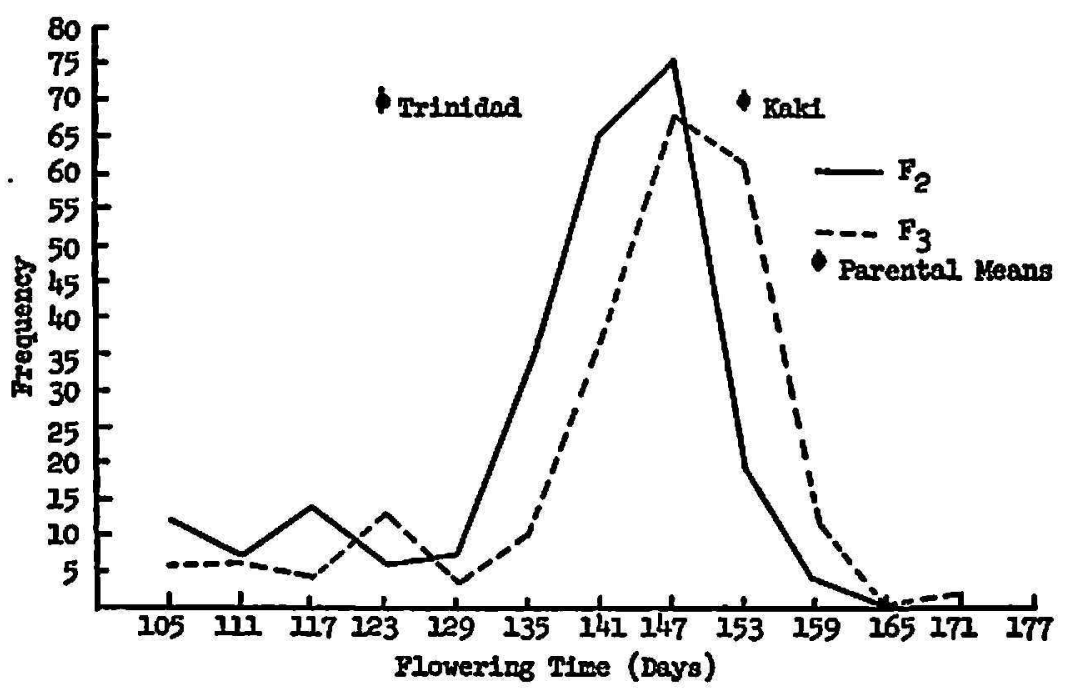

Fra. 1.-Frequency distribution of the $F_{2}$ and $F_{8}$ generations, and the parental means for date of flowering in the cross P.I. $5690 \mathrm{X}$ Kaki.

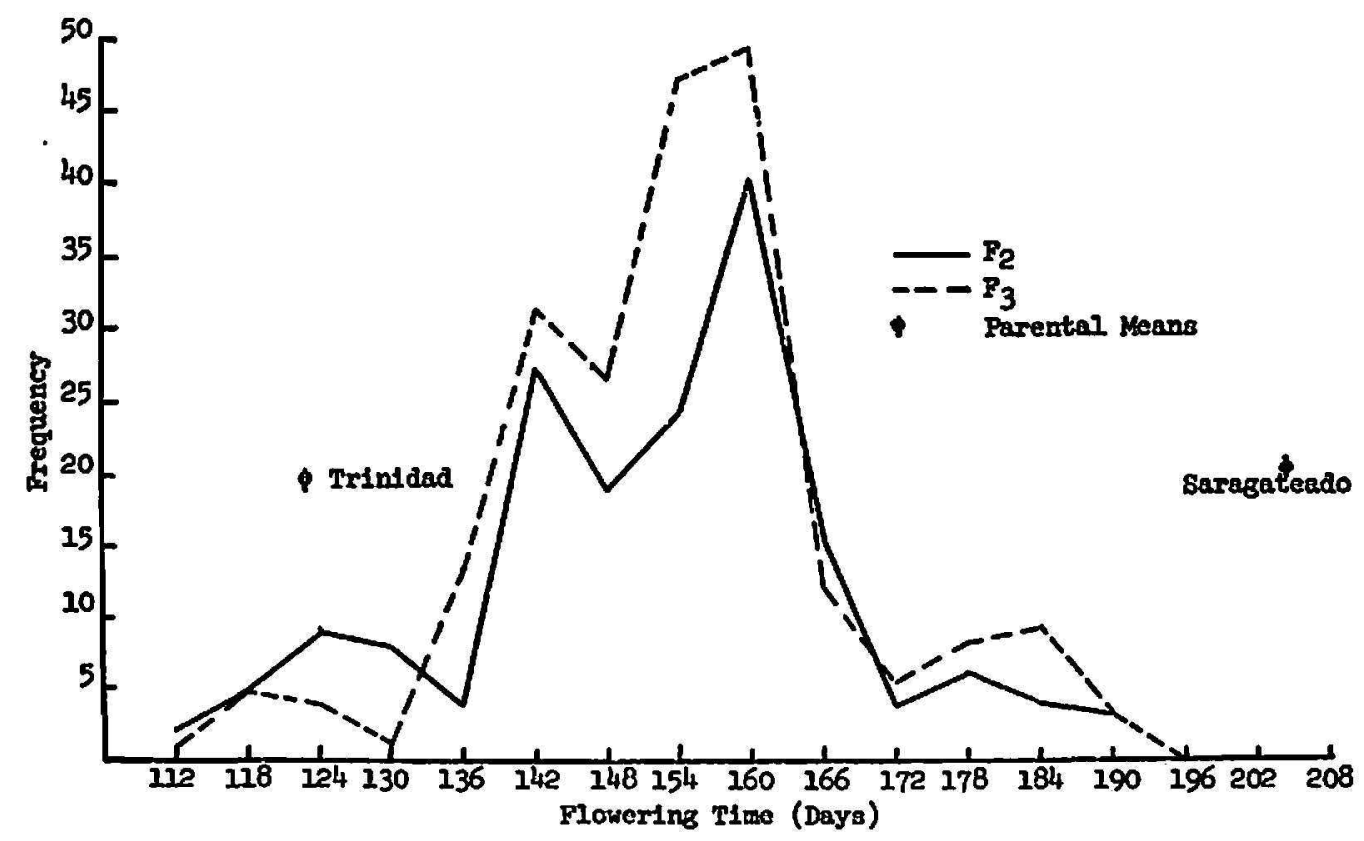

Fig. 2.-Frequency distribution of the $F_{2}$ and $F_{3}$ generations, and the parental means for date of flowering in the cross P.I. $5690 \mathrm{X}$ Saragateado.

\section{RESULTS}

The mean and range for date of flowering, plant height, seed weight, and number of seeds per pod of parental, $F_{2}$, and $F_{3}$ generations of five pigeonpea crosses are presented in table 1 . For all characters studied the range of variability was greater in $F_{2}$ and $F_{3}$ generations with increasing contrast 
in parents characteristics. The number of seeds per pod in segregating generations had a lower range of variability than the other characters studied. This seems to indicate that no appreciable progress in breeding could be

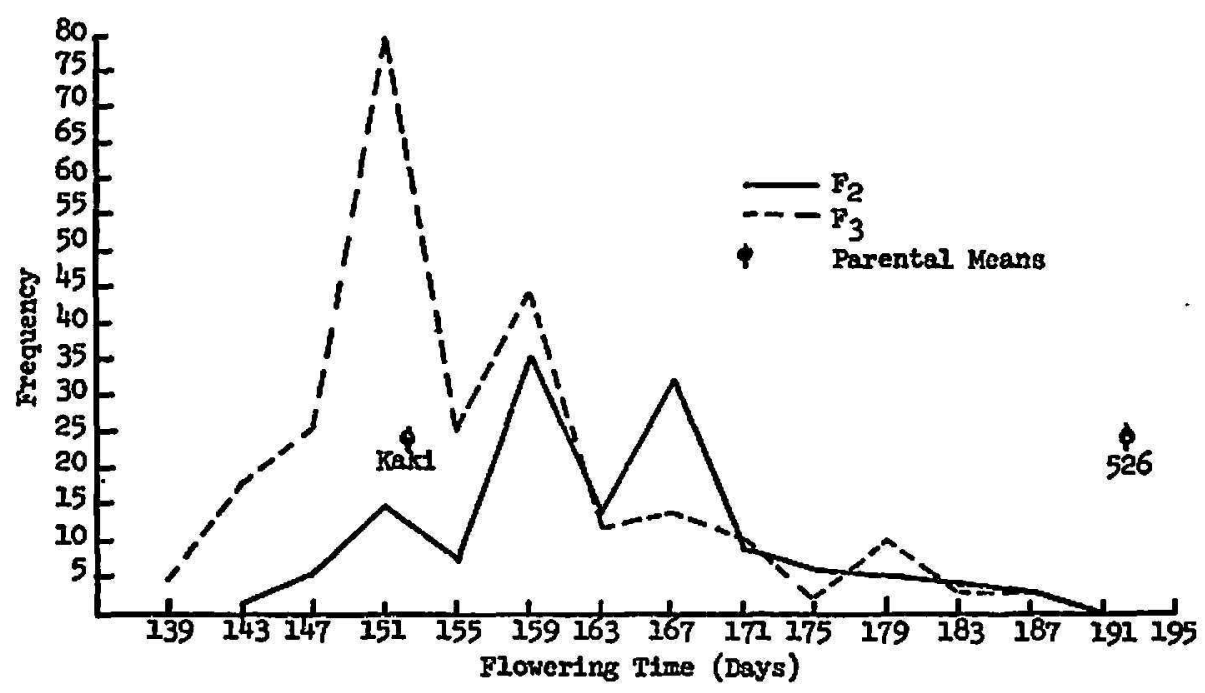

Fig. 3.-Frequency distribution of the $F_{2}$ and $F_{3}$ generations, and the parental means for date of flowering in the cross Kaki X 526.

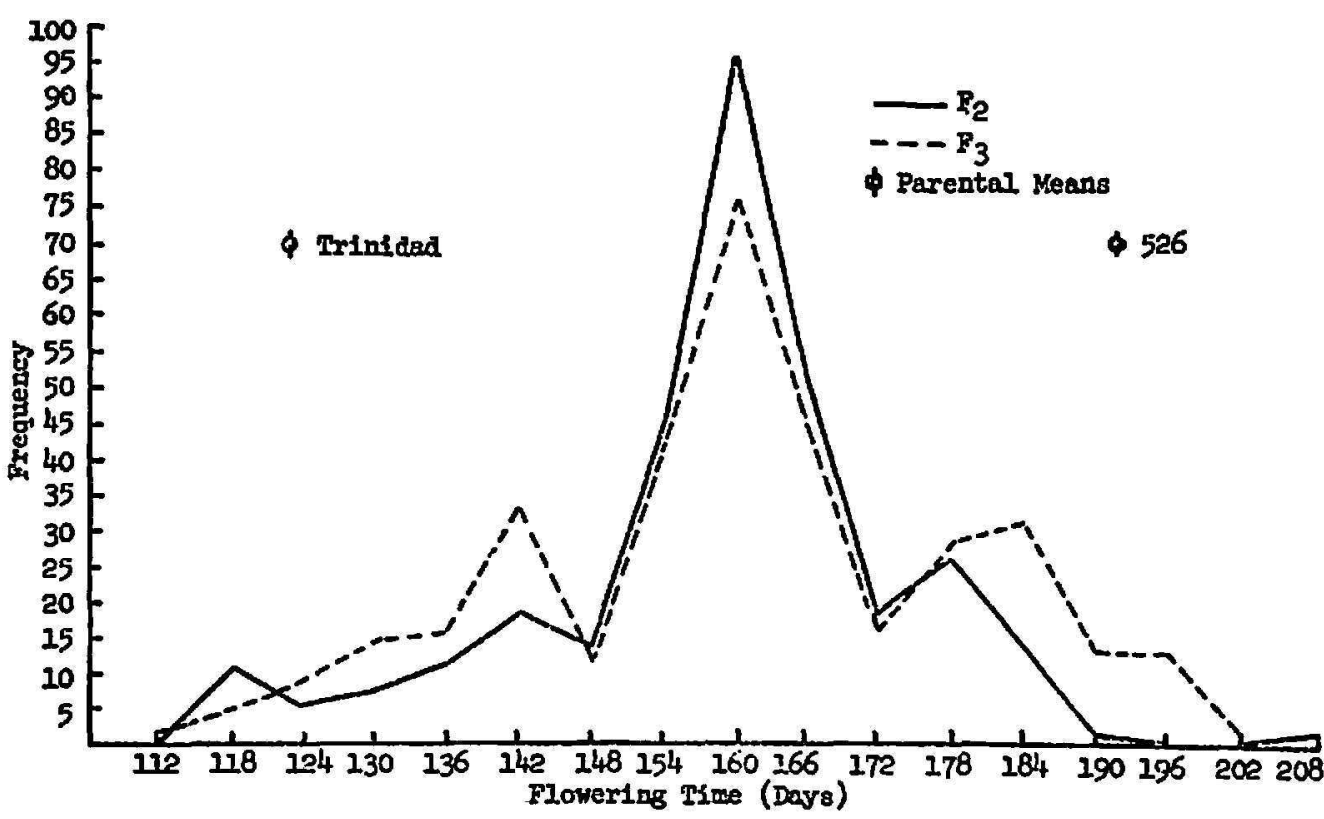

Fia. 4.-Frequency distribution of the $F_{2}$ and $F_{3}$ generations, and the parental means for date of flowering in the cross 526 X P.I. 5690.

made for this attribute. The means of the five crosses give additional evidence for this conclusion.

Frequency distributions for date of flowering of $F_{2}$ and $F_{3}$ plants and parental means are shown in figures 1 to 5 , inclusive, for the five pigeonpea crosses. Transgressive segregation for earliness and lateness was observed 
in crosses P.I. $5690 \mathrm{X}$ Kaki and Saragateado X 526. For all crosses, except Saragateado $\mathrm{X} 526$, the $F_{2}$ and $F_{3}$ distributions extended over the entire range of the parents. The $F_{2}$ and $F_{3}$ frequencies were intermediate and somewhat positively skewed toward the earlier bearing parent. This suggests earliness for flowering shows some dominance to lateness; however, because of the negative association of lateness with seed yield, there might be a tendency to select for earlier flowering plants as shown by the particular cross between the two late varieties, Saragateado X 526.

Frequency distributions for plant height are shown in figures 6 to 10, inclusive. This attribute follows a trend somewhat similar to date of flowering, i.e., the $F_{2}$ and $F_{3}$ plants were distributed over the entire range of the parents and means were intermediate when parents contrasted for this character. In two of the crosses, Saragateado X 526 and Kaki X 526,

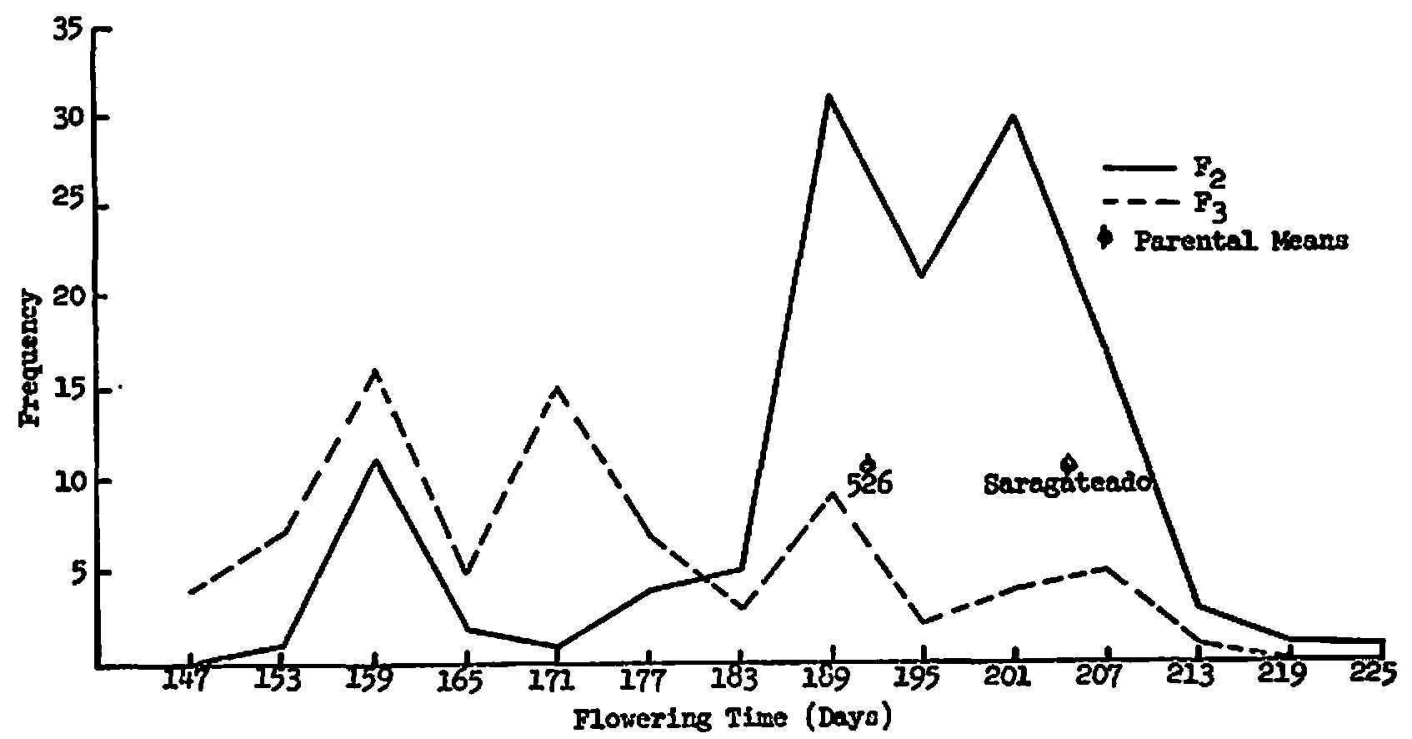

Fra. 5.-Frequency distribution of the $F_{2}$ and $F_{3}$ generations, and the parental means for date of flowering in the cross $526 \mathrm{X}$ Saragateado.

there was no significant contrast for plant height. The mean height for Kaki, Saragateado, and 526 was 6.5, 7.0, and 7.0 feet, respectively. Apparently, in these three varieties, the ceiling for number of genes for plant height has been attained and the mean remains the same for $F_{2}$ and $F_{3}$ plants, or the three entries have a similar gene system for plant height.

Figures 11 to 15 show graphically the frequency distribution for seed weight of $F_{2}$ and $F_{3}$ plants of the five crosses and the parental means. For all crosses the distribution is markedly skewed toward the heavier seed parent. This suggests that for the character seed weight, heavier seeds show some dominance over lighter seeds.

The coefficients of variation (table 2) for flowering date, height, seed weight, and number of seeds per pod were low, with the exception of num- 
ber of seeds per pod for cross Saragateado X 526 and 5690 X Saragateado. No known reference exists of previous research work with this crop; thus the degree of precision on the attributes studied cannot be compared.

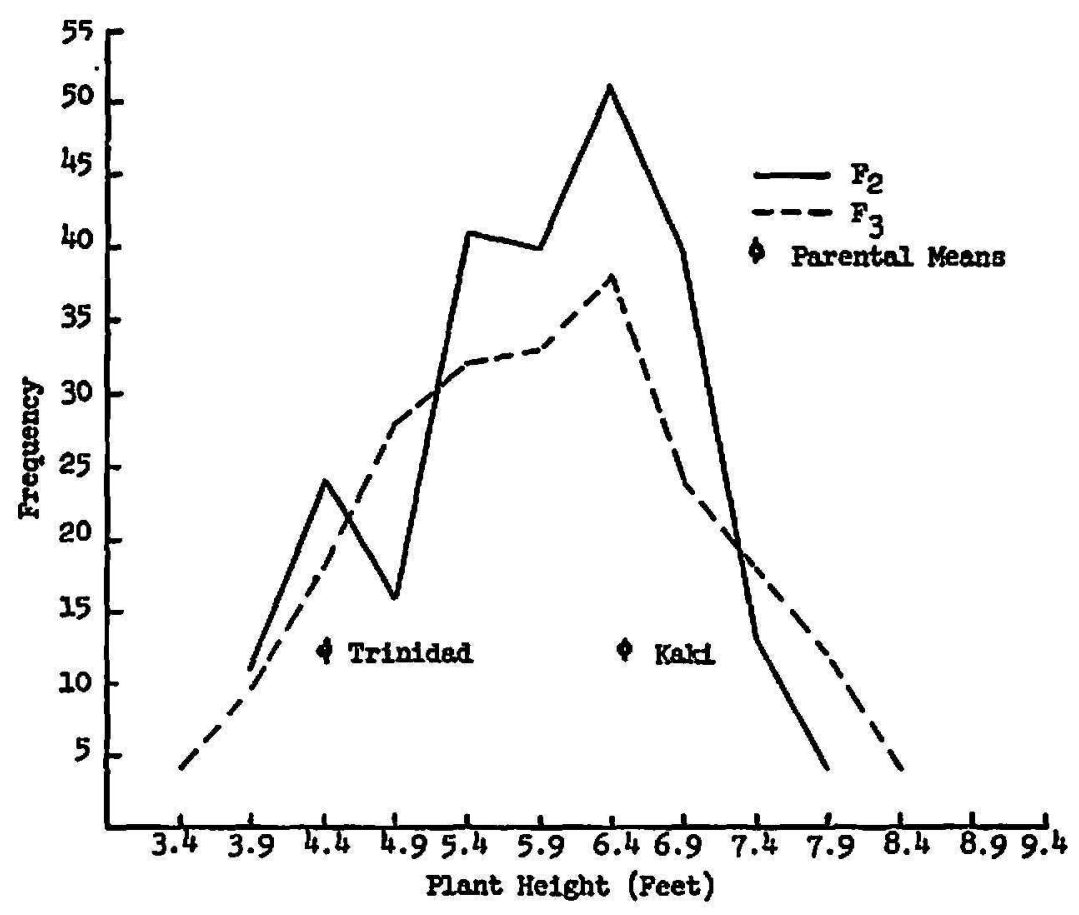

Fra. 6.-Frequency distribution of the $F_{2}$ and $F_{3}$ generations, and the parental means for plant height in the cross P.I. 5690 X_Kaki.

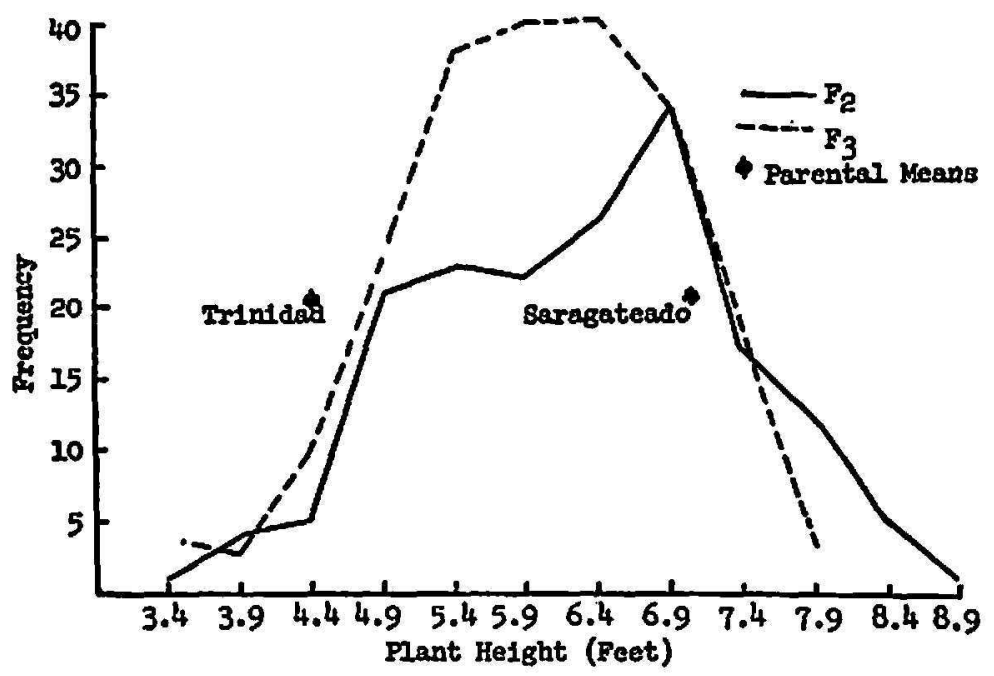

Fro. 7.-Frequency distribution of the $F_{2}$ and $F_{2}$ generations, and the parental means for plant height in the cross P.I. $5690 \mathrm{X}$ Saragateado.

These low coefficients of variation indicate a good degree of precision for the experiment of the attributes under consideration.

Heritability estimates for the $F_{2}$ and $F_{8}$ generations for all characters of 


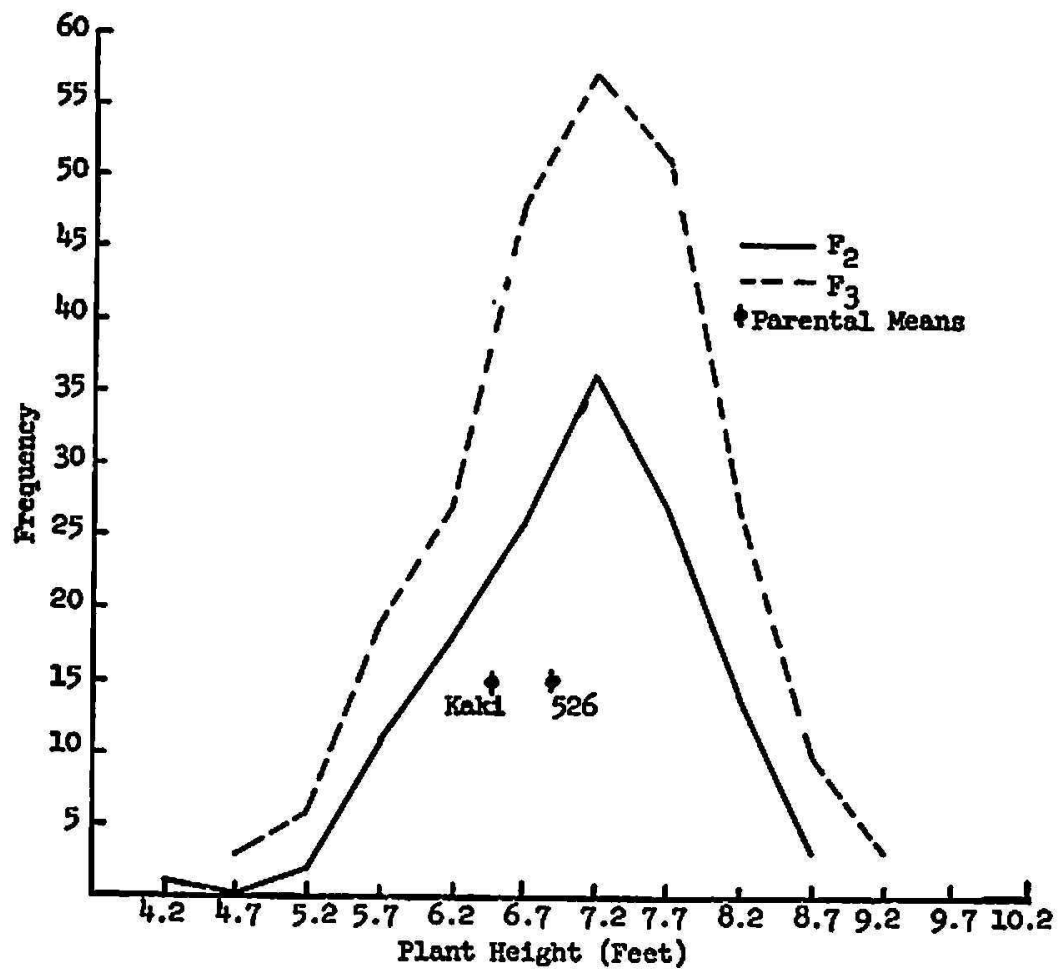

Fra. 8.-Frequency distribution of the $F_{2}$ and $F_{3}$ generations, and the parental means for plant height, in the cross Kaki X 526.

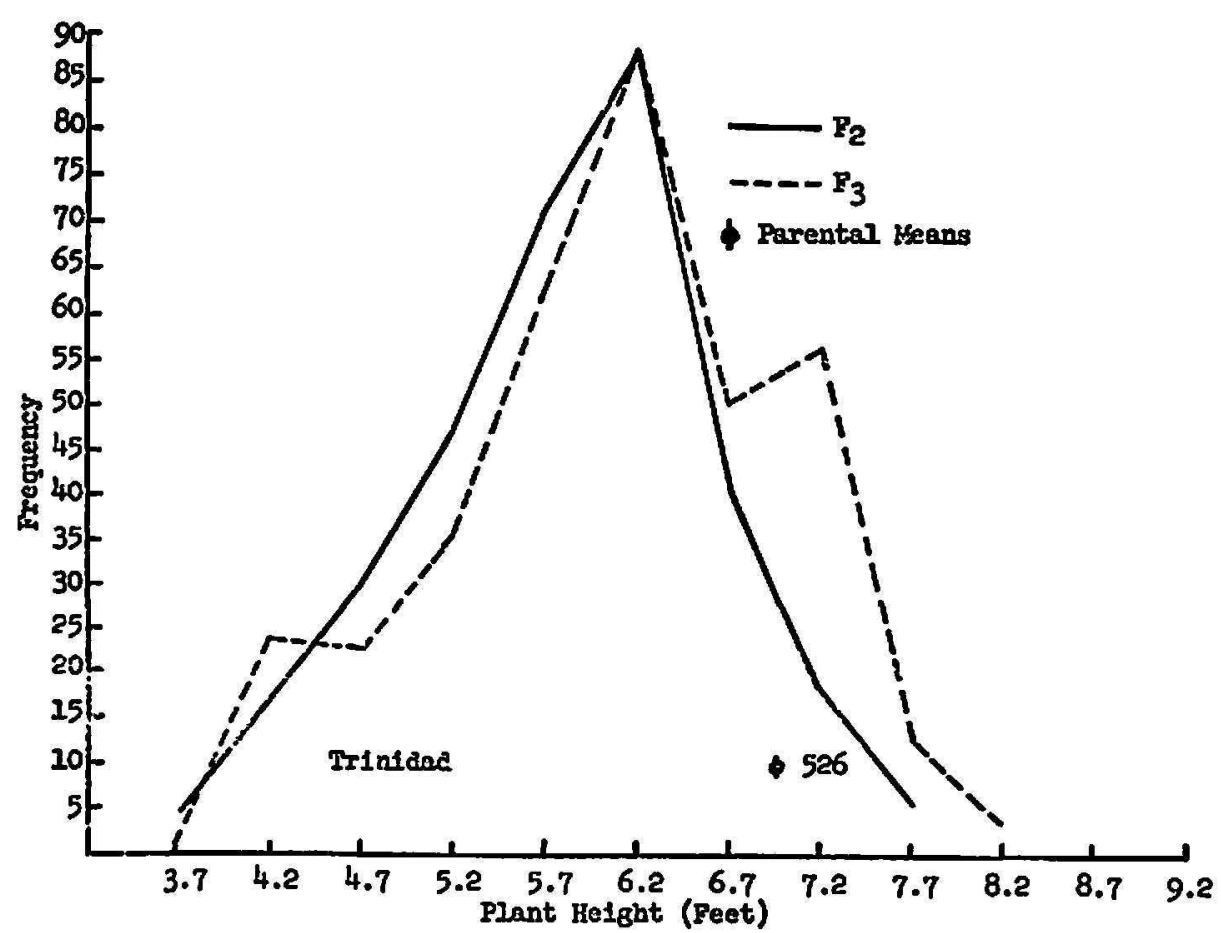

Fic. 9.-Frequency distribution of the $F_{2}$ and $F_{3}$ generations, and the parental means for plant height in the cross 526 X P.I. 5690 . 


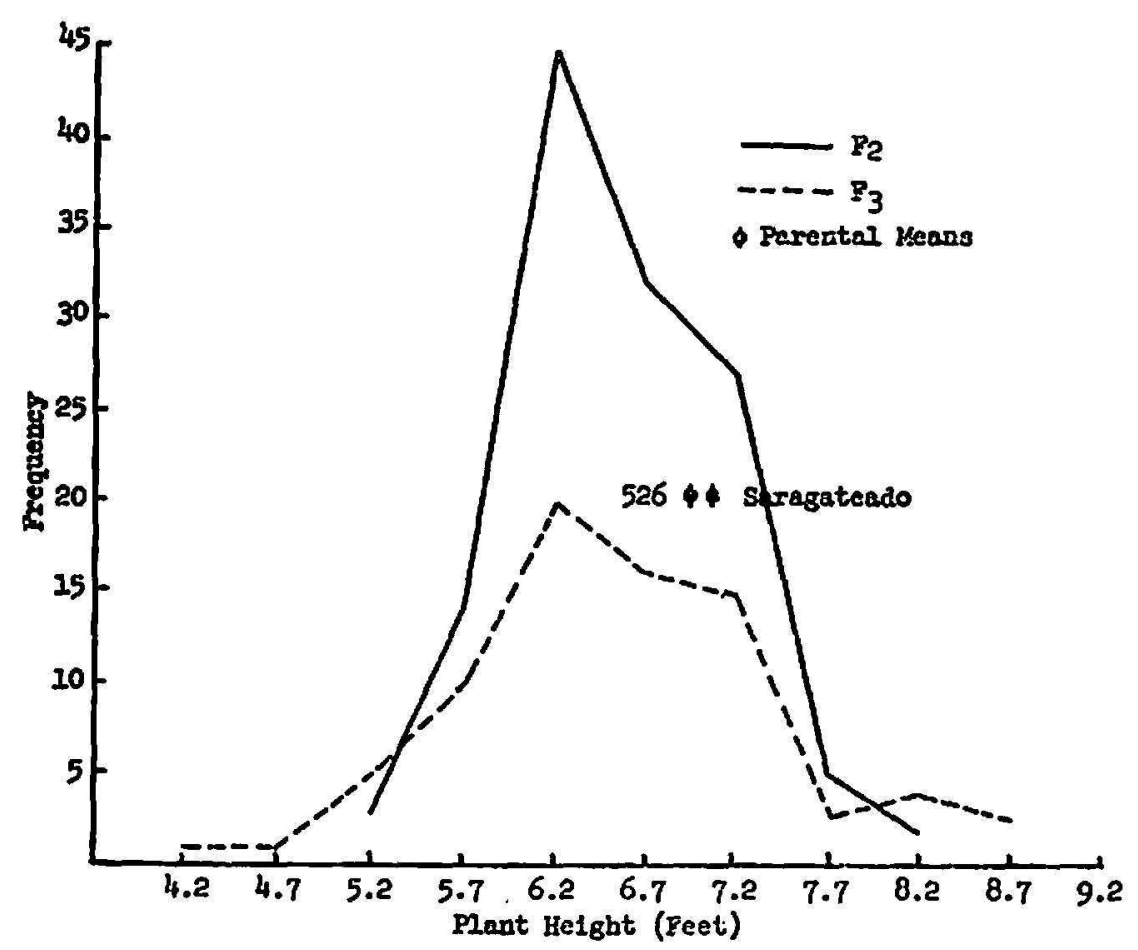

Fia. 10.-Frequency distribution of the $F_{2}$ and $F_{3}$ generations, and the parental means for plant height in the cross $526 \mathrm{X}$ Saragateado.

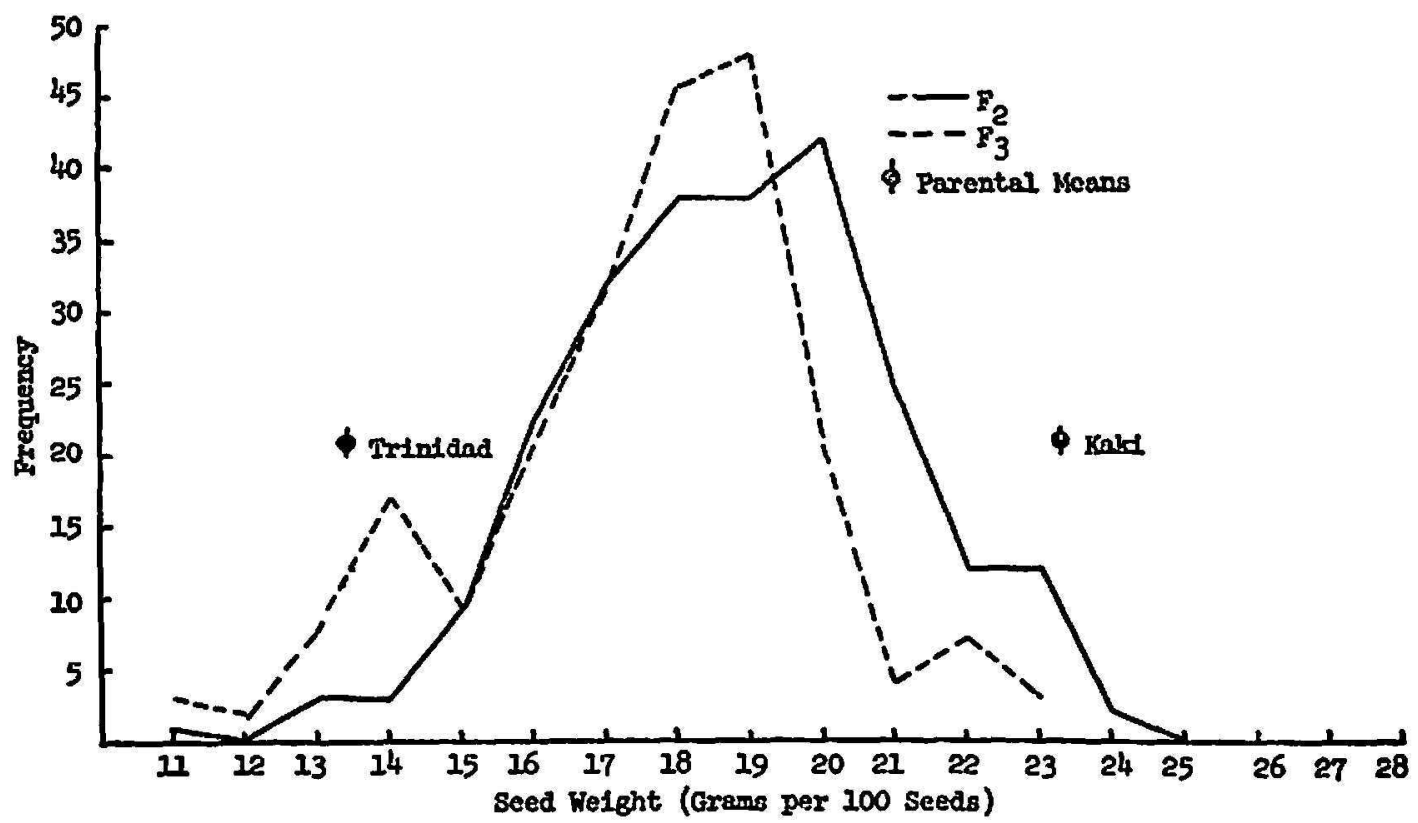

Fra. 11.-Frequency distribution of the $F_{2}$ and $F_{3}$ generations, and the parental means for seed weight in the cross P.I. $5690 \mathrm{X}$ Kaki.

the five pigeonpea crosses are presented in table 3 . Heritability values for date of flowering were high and comparable for all crosses.

Estimated heritabilities for plant height in $F_{2}$ and $F_{3}$ generations were similar in magnitude to those attained for date of flowering except for crosses Kaki X 526 and Saragateado X line 526. 
Seed weight, except for crosses Saragateado X 526 and P.I. 5690 X 526 in the $F_{2}$ generations, also showed a high heritability percentage and of similar magnitude as flowering and plant height.

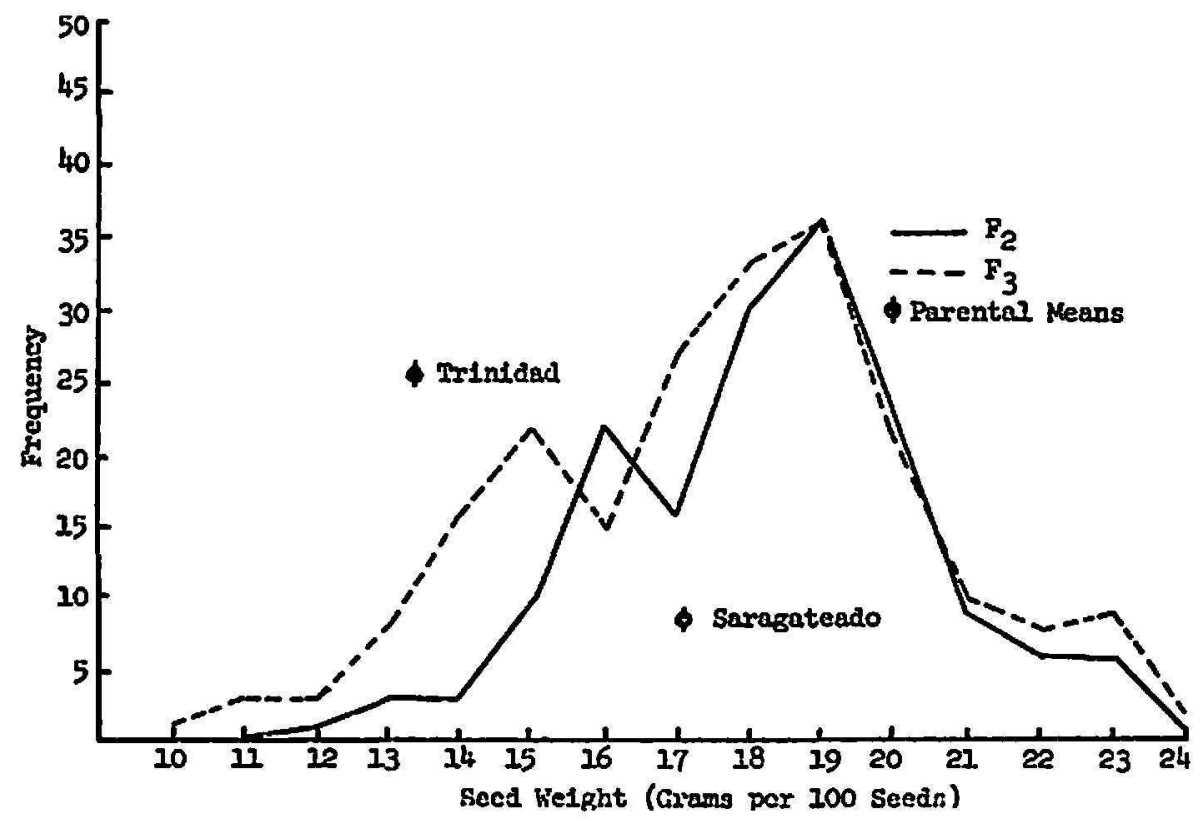

FrG. 12.-Frequency distribution of the $F_{2}$ and $F_{3}$ generations, and the parental means for seed weight in the cross P.I. $5690 \mathrm{X}$ Saragateado.

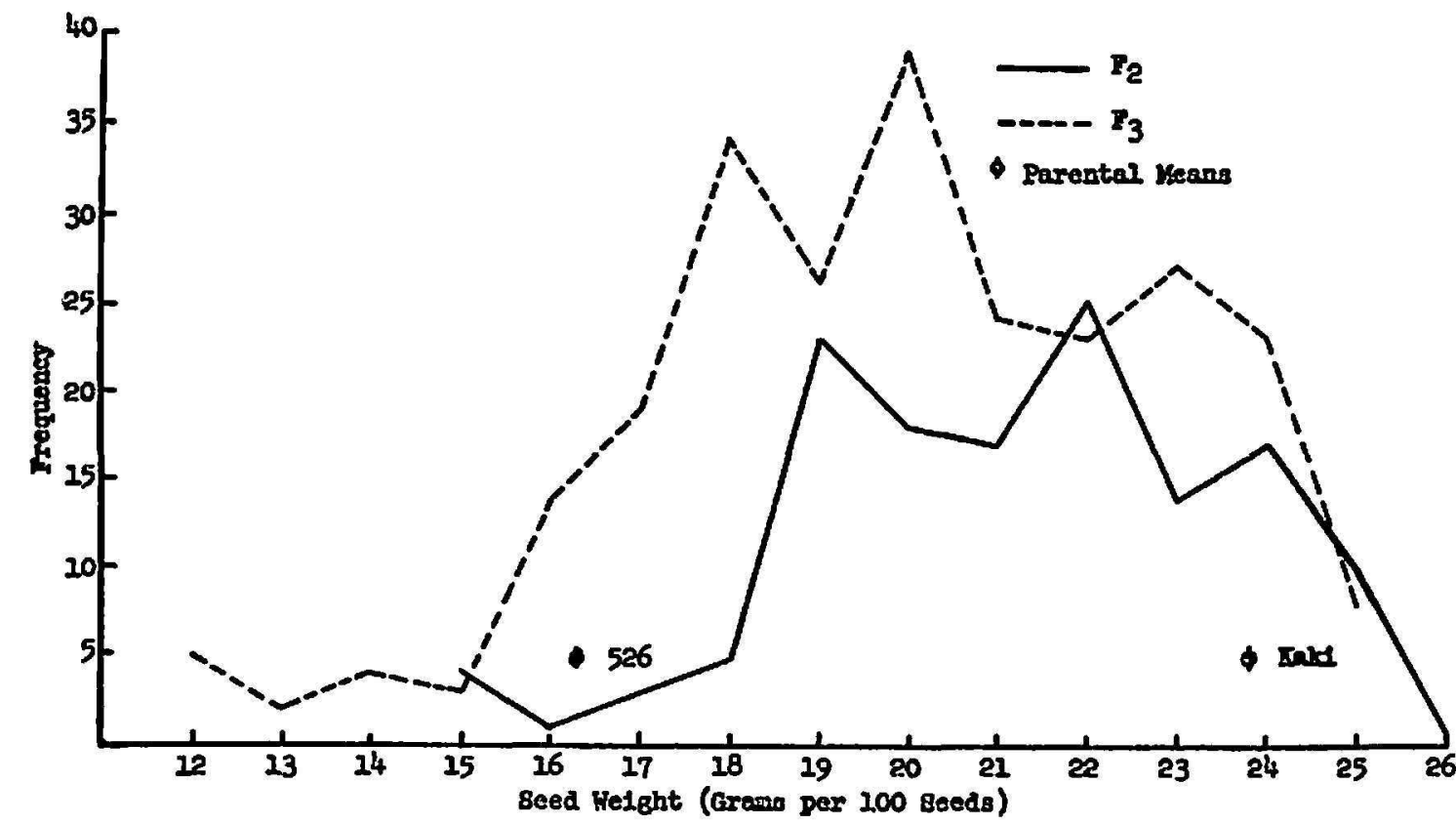

Fia. 13. - Frequency distribution of the $F_{2}$ and $F_{3}$ generations, and the parental means for seed weight in the cross Kaki X 526.

Number of seeds per pod showed the lowest heritability values for all traits of the five crosses. This low heritability for number of seeds per pod can be explained on the basis of a very narrow amount of genetic variation as indicated by the parental means and ranges in table 1 . 
Heritability values for seed yield and number of pods per plant were estimated for only one of the five crosses, Kaki X P.I. 5690. The heritability estimates for the other four crosses were too erratic because late parent

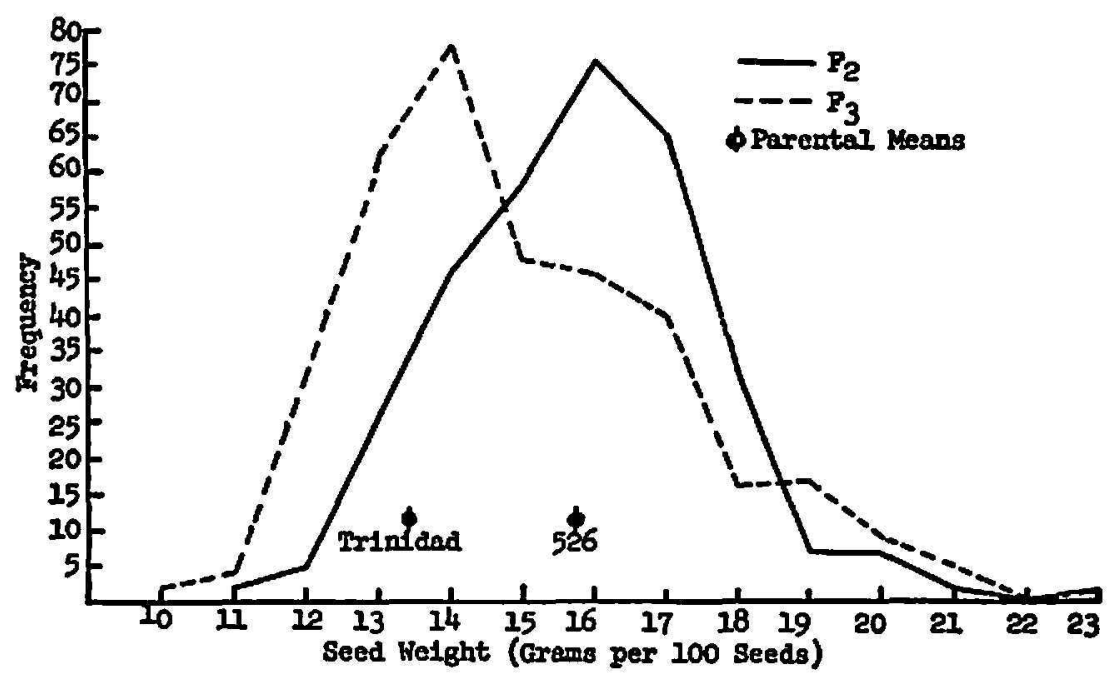

Fia. 14.-Frequency distribution of the $F_{2}$ and $F_{3}$ generations, and the parental means for seed weight in the cross 526 X P.I. 5690.

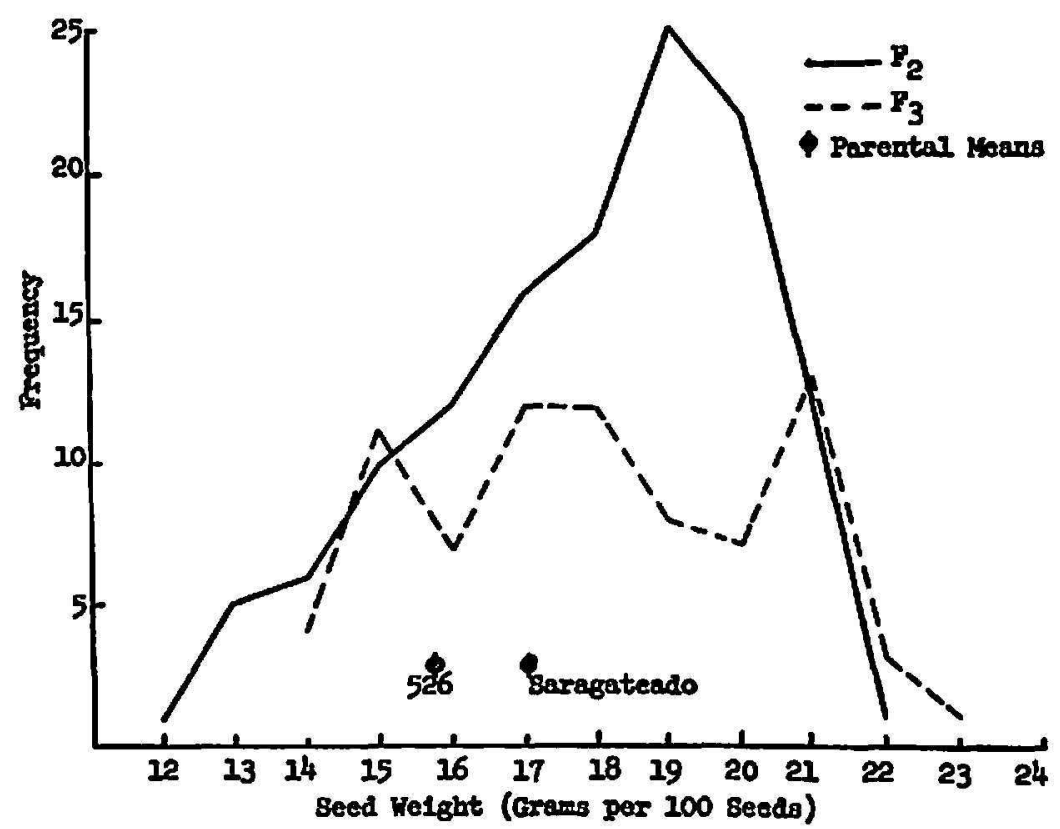

Fra. 15.-Frequency distribution of the $F_{2}$ and $F_{8}$ generations, and the parental means for seed weight in the cross $526 \mathrm{X}$ Saragateado.

varieties produced low seed yield thus were heavily infested with pod borers. They therefore were excluded from the analyses. Estimates of heritability for $F_{2}$ and $F_{3}$ generation were 45.1 and 52.1 percent for seed yield and 45.3 and 52.9 for number of pods per plant.

The genetic coefficients of variation are presented in table 4. In general, 
the highest coefficients of genetic variation were observed in crosses where the parents contrasted in the attributes under consideration. An exception can be observed in number of seeds per pod in cross Saragateado X 526

TABLE 2.-Coefficients of varialion (percent) for flowering date, plant height, seed weight, and number of seeds per pod of $F_{2}$ and $F_{3}$ generations of five pigeonpea crosses

\begin{tabular}{|c|c|c|c|c|}
\hline Generation & Flowering date & Plant height & Seed woight & $\begin{array}{l}\text { Number of seeds } \\
\text { per pod }\end{array}$ \\
\hline \multicolumn{5}{|l|}{ P.I. 5690 X Kaki } \\
\hline$F_{2}$ & 8.8 & 15.8 & 11.9 & 11.6 \\
\hline$F_{8}$ & 8.6 & 16.8 & 12.7 & 13.7 \\
\hline \multicolumn{5}{|c|}{ P.I. 5690 X Saragateado } \\
\hline$F_{2}$ & 10.5 & 14.5 & 12.1 & 14.9 \\
\hline$F_{z}$ & 9.2 & 14.2 & 15.2 & 21.5 \\
\hline \multicolumn{5}{|l|}{ Kaki X 526} \\
\hline$F_{2}$ & 5.5 & 9.3 & 10.2 & 11.5 \\
\hline$F_{8}$ & 6.1 & 9.0 & 14.2 & 12.1 \\
\hline \multicolumn{5}{|l|}{ P.I. $5690 \mathrm{X} 526$} \\
\hline$F_{2}$ & 9.5 & 13.7 & 10.6 & 12.6 \\
\hline$F_{2}$ & 12.1 & 14.5 & 14.3 & 17.2 \\
\hline \multicolumn{5}{|l|}{ Saragateado X 526} \\
\hline$F_{2}$ & 7.6 & 8.9 & 12.1 & 25.6 \\
\hline$F_{\mathrm{a}}$ & 10.0 & 13.2 & 12.9 & 13.9 \\
\hline
\end{tabular}

TABLE 3.-Heritability estimales (percent) for flowering date, plant height, seed weight, and number of seeds per pod in each of five pigeonpea crosses

\begin{tabular}{|c|c|c|c|c|c|}
\hline \multirow[b]{2}{*}{ Characters } & \multicolumn{5}{|c|}{ Herilability } \\
\hline & P.I. $56900 X$ & $\begin{array}{l}\text { P.I. } 5690 X \\
\text { Saragaleado }\end{array}$ & Kaki X 526 & P.I. ${ }_{526}^{5690 X}$ & $\begin{array}{c}\text { Saragaleado } \\
\times 526\end{array}$ \\
\hline \multicolumn{6}{|l|}{ Flowering date } \\
\hline$F_{2}$ & 72.9 & 81.8 & 72.5 & 76.9 & 60.7 \\
\hline$-F_{2}$ & 73.5 & 76.8 & 74.7 & 86.1 & 72.2 \\
\hline \multicolumn{6}{|l|}{ Plant_height } \\
\hline$F_{2}$ & 70.8 & 76.3 & 45.1 & 65.6 & 36.7 \\
\hline$F_{3}$ & 74.4 & 71.7 & 41.8 & 71.7 & 38.6 \\
\hline \multicolumn{6}{|l|}{ Seed weight } \\
\hline$F_{2}$ & 75.6 & 64.4 & 55.4 & 35.9 & 36.3 \\
\hline$F_{8}$ & 75.6 & 75.9 & 73.7 & 61.0 & 65.3 \\
\hline \multicolumn{6}{|c|}{ Number of seeds per pod } \\
\hline$F_{2}$ & -37.4 & 33.3 & -6.1 & -20.8 & 65.2 \\
\hline$F_{8}$ & 8.2 & 64.1 & 9.6 & 30.5 & 64.1 \\
\hline
\end{tabular}

where the genetic coefficient of variation was relatively large. This situation can be explained on the basis of a relatively small plant population, and small population mean, which biased the genetic coefficient of variation. 
TABLE 4.-Genetic coefficient of variability (percent) for flowering date, plant height, seed weight, and number of seeds per pod in $F_{2}$ and $F_{2}$ generations of five pigeonpea

crosses

\begin{tabular}{|c|c|c|c|c|}
\hline & $\begin{array}{l}\text { Flowpering } \\
\text { datc }\end{array}$ & $\begin{array}{l}\text { Plant } \\
\text { height }\end{array}$ & $\begin{array}{l}\text { Seed } \\
\text { weight }\end{array}$ & $\begin{array}{c}\text { Number of seeds } \\
\text { per pod }\end{array}$ \\
\hline \multicolumn{5}{|l|}{ P.I. 5690 X Kaki } \\
\hline $\boldsymbol{F}_{2}$ & 7.52 & 13.32 & 10.36 & -7.11 \\
\hline$F_{8}$ & 7.39 & 14.57 & 11.06 & 3.94 \\
\hline \multicolumn{5}{|c|}{ P.I. 5690 X Saragateado } \\
\hline$F_{2}$ & 9.50 & 12.64 & 9.72 & 8.66 \\
\hline$F_{\mathrm{a}}$ & 8.06 & 12.04 & 13.32 & 17.26 \\
\hline \multicolumn{5}{|l|}{ Kaki X 626} \\
\hline$F_{2}$ & 3.38 & 5.84 & 7.63 & -2.86 \\
\hline & 3.91 & 5.38 & 12.20 & 3.75 \\
\hline \multicolumn{5}{|l|}{ P.I. $5690 \times 526$} \\
\hline$F_{2}$ & 8.39 & 11.10 & 6.40 & 5.77 \\
\hline $\boldsymbol{F}_{\mathbf{8}}$ & 11.29 & 12.30 & 11.22 & 9.55 \\
\hline \multicolumn{5}{|l|}{ Saragateado X 526} \\
\hline$F_{2}$ & 5.95 & 5.43 & 7.29 & 19.07 \\
\hline$F_{8}$ & 8.54 & 8.22 & 8.73 & 19.19 \\
\hline
\end{tabular}

TABLE 5.-Genotypic and phenotypic correlations between all pairs of 4 traits measured in the $F_{2}$ generations for 5 pigeonpea crosses (genotypic correlations are on the left side of the diagonal, phenotypic on the right)

\begin{tabular}{|c|c|c|c|c|c|}
\hline Trail & Cross* & Flowering & Beight & Seed weight & Seeds per pod \\
\hline Flowering & $\begin{array}{l}1 \\
2 \\
3 \\
4 \\
5\end{array}$ & & $\begin{array}{r}0.61 \\
0.60 \\
-0.05 \\
0.46 \\
-0.24\end{array}$ & $\begin{array}{r}0.35 \\
-0.08 \\
-0.07 \\
-0.09 \\
-0.36\end{array}$ & $\begin{array}{r}0.22 \\
-0.25 \\
-0.31 \\
-0.01 \\
-0.25\end{array}$ \\
\hline Height & $\begin{array}{l}1 \\
2 \\
3 \\
4 \\
5\end{array}$ & $\begin{array}{r}0.67 \\
0.75 \\
0.30 \\
0.71 \\
-0.32\end{array}$ & & $\begin{array}{l}0.26 \\
0.01 \\
0.06 \\
0.12 \\
0.18\end{array}$ & $\begin{array}{l}0.36 \\
0.06 \\
0.24 \\
0.37 \\
0.14\end{array}$ \\
\hline Seed weight & $\begin{array}{l}1 \\
\mathbf{2} \\
\mathbf{3} \\
\mathbf{4} \\
\mathbf{5}\end{array}$ & $\begin{array}{r}0.65 \\
-0.03 \\
0.01 \\
0.07 \\
-0.31\end{array}$ & $\begin{array}{r}0.36 \\
-0.12 \\
0.22 \\
0.36 \\
-0.33\end{array}$ & & $\begin{array}{r}0.21 \\
0.06 \\
-0.06 \\
0.06 \\
0.44\end{array}$ \\
\hline Seeds per pod & $\begin{array}{l}1 \\
2 \\
3 \\
4 \\
5\end{array}$ & $\begin{array}{r}0.68 \\
-0.27 \\
0.97 \\
0.60 \\
-0.35\end{array}$ & $\begin{array}{r}0.47 \\
-0.03 \\
0.26 \\
0.54 \\
0.10\end{array}$ & $\begin{array}{r}0.22 \\
-0.11 \\
1.46 \\
0.03 \\
0.29\end{array}$ & \\
\hline
\end{tabular}

* 1, 2, 3, 4, 5 denotes P.I. 5690 X Kaki, P.I. 5690 X Saragateado, Kaki X 526, $526 \mathrm{X}$ P.I. 5690 and $526 \mathrm{X}$ Saragateado, respectively. 
To study intercharacter associations, correlation coefficients were computed for the four attributes under consideration. Phenotypic and genotypic correlations are presented in tables 5 and 6 . In general, the genotypic correlations for any pair of traits seem to be of similar magnitude. Likewise,

TABLe 6.-Genotypic and phenolypic correlations between all pairs of 4 traits measured in the $F_{3}$ generation for 5 pigeonpea crosses (genotypic correlations are on the left side of the diagonal, phenolypic on the right)

\begin{tabular}{|c|c|c|c|c|c|}
\hline Traif & Cross2 & Flowering & Beight & Seed weight & Seeds per pod \\
\hline Flowering & $\begin{array}{l}1 \\
2 \\
3 \\
4 \\
5\end{array}$ & & $\begin{array}{r}0.44 \\
0.38 \\
-0.01 \\
0.40 \\
0.17\end{array}$ & $\begin{array}{r}0.28 \\
-0.23 \\
0.15 \\
-0.20 \\
-0.51\end{array}$ & $\begin{array}{r}0.06 \\
0.02 \\
-0.30 \\
-0.24 \\
-0.70\end{array}$ \\
\hline Height & $\begin{array}{l}1 \\
2 \\
3 \\
4 \\
5\end{array}$ & $\begin{array}{r}0.43 \\
0.49 \\
0.38 \\
0.65 \\
-0.14\end{array}$ & & $\begin{array}{r}0.16 \\
-0.11 \\
0.11 \\
0.03 \\
0.16\end{array}$ & $\begin{array}{l}0.48 \\
0.20 \\
0.39 \\
0.37 \\
0.29\end{array}$ \\
\hline Seed weight & $\begin{array}{l}1 \\
2 \\
3 \\
4 \\
5\end{array}$ & $\begin{array}{r}0.39 \\
-0.23 \\
0.37 \\
-0.18 \\
-0.60\end{array}$ & $\begin{array}{r}0.22 \\
-0.25 \\
0.28 \\
0.09 \\
-0.07\end{array}$ & & $\begin{array}{l}0.09 \\
0.05 \\
0.06 \\
0.19 \\
0.41\end{array}$ \\
\hline Seeds per pod & $\begin{array}{l}1 \\
2 \\
3 \\
4 \\
5\end{array}$ & $\begin{array}{r}0.69 \\
0.16 \\
0.53 \\
-0.17 \\
-0.72\end{array}$ & $\begin{array}{l}1.56 \\
0.21 \\
1.09 \\
0.53 \\
0.34\end{array}$ & $\begin{array}{r}0.07 \\
-0.02 \\
-0.32 \\
0.34 \\
0.29\end{array}$ & \\
\hline
\end{tabular}

1 1, 2, 3, 4, 5 denotes P.I. 5690 X Kaki, P.I. 5690 X Saragateado, Kaki X 526, 526 X P.I. 5690, $526 \mathrm{X}$ Saragateado, respectively.

TABLE 7.-Genotypic and phenolypic correlations of 6 traits measured in the $F_{2}$ generation for P.I. $5690 X$ Saragateado pigeonpea cross (genotypic correlations are on the left side of the diagonal, phenotypic on the right)

\begin{tabular}{lrrrrrr}
\hline \multicolumn{1}{c}{ Trail } & Yield & $\begin{array}{r}\text { Number } \\
\text { of pods }\end{array}$ & Flowering & Height & $\begin{array}{c}\text { Seed } \\
\text { veight }\end{array}$ & $\begin{array}{r}\text { Number } \\
\text { of seeds } \\
\text { per pod }\end{array}$ \\
\hline Yield & & 0.90 & -0.14 & 0.25 & 0.11 & 0.39 \\
Number of pods & 0.91 & & -0.11 & 0.20 & -0.14 & 0.31 \\
Flowering & -0.12 & -0.08 & & 0.60 & -0.08 & -0.25 \\
Height & 0.25 & 0.18 & 0.75 & & 0.01 & 0.06 \\
Seed weight & 0.09 & -0.21 & -0.03 & -0.12 & & 0.06 \\
Number of seeds per pod & 0.52 & 0.30 & -0.27 & -0.03 & -0.11 & \\
\hline
\end{tabular}


the values observed for any two characters are rather similar for the five crosses.

Plant height, in general, is highly positively correlated with late flowering and tends to be negatively correlated with seed weight and number of seeds per pod. As mentioned previously, late flowering plants are subject to more severe attack by pod borers and other insects than early flowering types,

TABLE 8.-Genotypic and phenotypic correlations between all pairs of 6 traits measured in the $F_{8}$ generation for P.I. $6690 X$ Saragateado pigeonpea cross (genotypic correlations are on the left side of the diagonal, phenotypic on the right)

\begin{tabular}{lrrrrrr}
\hline \multicolumn{1}{c}{ Trait } & Yield & $\begin{array}{r}\text { Number } \\
\text { of pods }\end{array}$ & Flowering & Height & $\begin{array}{r}\text { Seed } \\
\text { weight }\end{array}$ & $\begin{array}{r}\text { Number } \\
\text { of seeds } \\
\text { per pod }\end{array}$ \\
\hline Yield & & 0.91 & -0.07 & 0.33 & 0.29 & 0.11 \\
Number of pods & 0.93 & & -0.04 & 0.30 & 0.10 & 0.11 \\
Flowering & -0.04 & 0.03 & & 0.38 & -0.23 & 0.02 \\
Height & 0.34 & 0.31 & 0.49 & & -0.11 & 0.20 \\
Seed weight & 0.31 & 0.10 & -0.23 & -0.25 & & 0.05 \\
Number of seeds per pod & 0.05 & -0.01 & 0.16 & 0.21 & -0.02 & \\
\hline
\end{tabular}

TABLE 9.-Genotypic and phenotypic correlations of 6 traits measured in the $F_{2}$ generation for $696 X$ X P.I. 5690 pigeonpea cross (genotypic correlations are on the left side of the diagonal, phenotypic on the right)

\begin{tabular}{lrrrrrr}
\hline \multicolumn{1}{c}{ Trait } & Yield & $\begin{array}{r}\text { Number } \\
\text { of pods }\end{array}$ & Flowering & Height & $\begin{array}{r}\text { Seed } \\
\text { weight }\end{array}$ & $\begin{array}{r}\text { Number } \\
\text { of seeds } \\
\text { per pod }\end{array}$ \\
\hline Yield & & 0.89 & -0.03 & 0.46 & 0.13 & 0.52 \\
Number of pods & 0.89 & & 0.05 & 0.42 & -0.08 & 0.40 \\
Flowering & -0.17 & 0.17 & & 0.46 & -0.09 & -0.01 \\
Height & 0.47 & 0.39 & 0.71 & & 0.12 & 0.37 \\
Seed weight & 0.19 & -0.10 & 0.06 & 0.36 & & 0.06 \\
Number of seeds per pod & 0.57 & 0.35 & 0.60 & 0.54 & 0.03 & \\
\hline
\end{tabular}

because insect populations are greater in numbers later in the season. Late types also are more exposed to environmental stresses such as higher temperature and drought conditions which affect yield and its components adversely.

Genotypic and phenotypic correlations between all six pairs of traits which include yield and yield components are presented in tables 7 to 10 . These data were included even though the authors are aware that the number of parental plants is small. Interesting data resulted from two crosses in which the parents showed extreme contrast in most traits. Seed yield is highly positively correlated with number of pods per plant, as expected, in 
both crosses. Of particular interest is the negative correlation in both crosses between seed yield and late flowering date. Since pigeonpea is a seasonal crop and very sensitive to photoperiodism, the amount of flower induction apparently is smaller in late flowering types than in early ones. Correlations between other traits followed the same trend as those discussed earlier.

\section{DISCUSSION}

There was much greater variation, in general, in seed weight, plant height, and flowering date for all crosses than in number of seeds per pod. The heritable and non-heritable components of variation were estimated with the help of some genetic parameters such as heritability and genetic coefficients of variation.

TABLE 10.-Genotypic and phenotypic correlations between all pairs of 6 traits measured in the $F_{2}$ generation for $626 X$ P.I. 6690 pigeonpea cross (genolypic correlations are on the left side of the diagonal, phenotypic on the right)

\begin{tabular}{lrrrrrr}
\hline \multicolumn{1}{c}{ Trail } & Yield & $\begin{array}{r}\text { Number } \\
\text { of pods }\end{array}$ & Flowering & Beight & $\begin{array}{r}\text { Seed } \\
\text { weight }\end{array}$ & $\begin{array}{r}\text { Number } \\
\text { of seeds } \\
\text { per pod }\end{array}$ \\
\hline Yield & & 0.90 & -0.18 & 0.45 & 0.27 & 0.62 \\
Number of pods & 0.90 & & -0.07 & 0.43 & 0.01 & 0.45 \\
Flowering & -0.30 & -0.02 & & 0.40 & -0.20 & -0.24 \\
Height & 0.46 & 0.41 & 0.55 & & 0.03 & 0.37 \\
Seed weight & 0.34 & 0.04 & -0.18 & 0.09 & & 0.19 \\
Number of seeds per pods & 0.83 & 0.55 & -0.17 & 0.53 & 0.34 & \\
\hline
\end{tabular}

High heritability values were obtained for some of the characters studied, i.e., flowering date, plant height, and seed weight. The relatively high heritability values for flowering date and plant height might justify the selection for these characters in $F_{2}$ and $F_{3}$ segregating generations. These traits apparently are not affected largely by environmental factors, thus genetic advances under selection would be expected to be high.

In two particular crosses, namely Saragateado X 526 and Kaki X 526, plant height heritability values obtained were 36.7 and 45.1 for $F_{2}$ generation and 38.6 and 41.8 for $F_{3}$ generation, respectively. The low values obtained for these two crosses seem to be due to the small genetic variation for this trait in the parents involved. Line 526 is derived from radiationtreated Kaki, with similar mean plant height. We therefore can assume that the gene system for plant height is the same or very similar for both entries. Saragateado is a late-flowering, tall variety with a mean plant height equal to Kaki and line 526. This reasoning could be explained based on the findings that the progenies from the crosses involving these parents have a 
mean plant height equal to that of the parents and also a small genetic variance as indicated in tables 1 and 4.

Seed weight heritability was next highest to flowering date and plant height. Seed weight is one of the yield components; therefore, the number of genes responsible for the expression of this trait should be smaller than for total yield and should be less affected by environmental factors. In general, the complexly-inherited characteristics have lower heritability than those inherited simply. The genetic coefficients of variation for seed weight also were relatively large for all crosses, thus, good genetic progress through selection could be made for this trait whenever a good screening technique is employed during the early segregating generations.

Small genetic variation and heritability estimates were obtained for number of seeds per pod. Even though wide ranges were observed for this attribute, the extremes were represented by few plants and the means were practically the same for parental, $F_{2}$ and $F_{3}$ populations. Not too much progress by selection could be expected for this yield component from the parental material used in this study. All four parents involved in this study had similar or the same number of seeds per pod. Observations made by Abrams 4 in crosses between Florido, a 7 to 8 and Kaki, a 4 to 5 seedper-pod variety tend to indicate that 1 or 2 more seeds per pod on the average could be incorporated in selected progenies from this particular cross.

Heritability estimates for seed yield and number of pods per plant made for cross P.I. $5690 \mathrm{X}$ Kaki indicated that these characters were influenced by non-heritable effects. These results are in close agreement with the work done by Weber and Moorthy (20) and Mahmud and Kramer (12), in soybeans, another legume crop, for early generation segregating populations, and substantiate the established belief among plant breeders that selection for yield should be based upon progeny test rather than upon individual plant values.

The heritability values in $F_{3}$ generation were higher in general than in $F_{2}$ for all traits in the five crosses. This trend was expected because both generations were grown in the same year and in the same location, therefore reducing the genotype $\mathrm{X}$ year and genotype $\mathrm{X}$ location interactions to a minimum. Under these conditions the additive genetic variance would show greater expression in $F_{3}$ generation, as expected.

It appears probable that these pigeonpea varieties differ in some genes, conditioning most characters studied. Thus, plus and minus gene effects conditioning an attribute in different parents permitted a complementary type of gene action in $F_{2}$ and $F_{3}$ segregates. This would explain the indicated transgressive segregation observed in $F_{2}$ and $F_{3}$ generations for some attributes of the five crosses. The characteristic number of seeds per pod does

4 Unpublished data. 
not show this complementary type of gene action in the $F_{2}$ and $F_{3}$ segregates as shown in table 1 . The four parents used in this study apparently have a similar gene system for number of seeds per pod.

With the exception of number of pods per plant, the correlations between seed yield and other traits were not sufficiently great to provide reliable indications for yield. The phenotypic and genotypic correlations between seed yield and number of pods per plant was high, 0.90 and 0.9 . We might expect to improve seed yield by selecting for large number per pods. However, its low heritability, 45.3 and 52.1 percent in $F_{2}$ and $F_{3}$ generations, tends to indicate that not too much progress for seed yield improvement could be expected by selecting for large number of pods per plant. The initial selection should perhaps be directed to seed weight which has a relatively high heritability, postponing selection for number of pods per plant. According to Frey (6) and Jones and Frey (10), heritability of a trait approaches its maximum in successive generations following hybridization, and selection for number of seeds per plant could be based on counts for normal planting rates to avoid the environmental effect associated with spaced plants.

All other genotypic and phenotypic correlations between pair of traits were of too small a magnitude to attain maximum values for a given pair of traits.

\section{SUMMARY}

Three varieties and an irradiation-derived line of pigeonpeas were used as parents in five crosses as follows: P.I. $5690 \mathrm{X}$ Kaki, P.I. $5690 \mathrm{X}$ Saragateado, P.I. 5690 X 526, Kaki X 526, and Saragateado X 526.

The $F_{2}, F_{3}$ and parents of each cross were planted in the field at the Isabela Substation during 1966-67 in a randomized block design with three replicates.

Genotypic variability was studied and genotypic and phenotypic correlations were calculated for all the crosses in the $F_{2}$ and $F_{3}$ generations.

Genetic coefficients of variation and heritability estimates were computed for four traits in five crosses and for six traits in one particular cross. Frequency distributions are shown for date of flowering, plant height, and seed weight.

There was much greater variation for all crosses, in general, in seed weight, plant height, and flowering date than in number of seeds per pod.

With the exception of number of pods per plant the correlations between seed yield and other traits were not great enough to provide reliable indications for yield. The phenotypic and genotypic correlations between seed yield and number of pods per plant were high, above 0.90 . However, their low heritability, 45.3 and 52.1 percent in $F_{2}$ and $F_{3}$ generations, tends to 
indicate that not too much progress could be expected for seed yield improvement by selecting for large number of pods per plant.

Good progress by selection could be made by breeders in traits such as flowering date, plant height, and seed weight which showed high heritability values.

\section{RESUMEN}

Para este trabajo se cruzaron tres variedades de gandures y una línea obtenida mediante la irradiación de la variedad Kaki, en cinco combinaciones, a saber: P.I. 5690 X Kaki, P.I. 5690 X Saragateado, P.I. 5690 X 526, Kaki X 526 y Saragateado X 526.

Los padres y las generaciones $F_{2}$ y $F_{3}$ de cada cruce se sembraron en la Subestación de Isabela durante el año 1966-67 en un diseño de bloques distribuidos al azar, con tres repeticiones.

Se estudió la variabilidad genotípica y se calcularon las correlaciones fenotípicas y genotípicas para todos los cruces en la generaciones $F_{2}$ y $F_{3}$.

Los coeficientes genéticos de variación y los estimados de heredabilidad se calcularon para cuatro caracteres en los cinco cruces y para seis caracteres en un cruce en particular. Se presentan datos sobre la frecuencia de la florecida, altura de las plantas y peso de la semilla.

En general, fue mayor la variación en todos los cruces respecto a la altura de las plantas, florecida y peso de la semilla, que en cuanto al número de semillas por vaina.

Con la excepción del número de vainas por planta, las correlaciones entre la producción y los demás caracteres no fueron lo suficientemente altas como para constituir una indicación confiable respecto a la producción. Las correlaciones genotípicas y fenotípicas entre la producción y el número de vainas por planta fueron altas, excediendo 0.90 . Sin embargo, los bajos porcentajes de heredabilidad en las generaciones $F_{2}$ y $F_{3}(45.3$ y 52.1 , respectivamente) tienden a indicar que no ha de lograrse un aumento en la producción si la selección se hace a base de que las plantas tengan muchas vainas.

En cambio, la selección en las primeras generaciones dará buenos resultados en el caso de tales caracteres como la florecida, altura de las plantas y peso de la semilla, que demostraron altos valores de heredabilidad.

\section{LITERATURE CITED}

1. Bartley, B. G., and Weber, C. R., Heritable and non heritable relationships and variability of agronomic characters in successive generations of soybean crosses, Agron. J. 44: 487-93, 1952.

2. Brim, C. A., and Cockerham Clark, C., Inheritance of quantitative characters in soybeans, Crop Sci $1: 187-90,1961$.

3. Burton, G. W., Quantitative Inheritance in pearl millet (Pennisetum glaucum), Agron.J. 4s: 409-17, 1951. 
4. - Quantitative inheritance in grasses, Proc. 6th Int. Grassland Congr. 1: 277-83, 1952.

5. Fiuzat, Y., and Atkins, R. E. Genetic and environmental variability in segregating barley populations. Agron. J. 45: 414-20, 1953.

6. Frey, K. J., Inheritance and heritability of heading date in barley, Agron. $J$. 46: 226-28, 1954.

7. Frey, K. J. and Horner, T., Comparison of actual and predicted gains in barley selection experiments, Agron. J. 47: 186-88, 1955.

8. - - Heritability in standard units. Agron. J. 49: 59-62, 1957.

9. Grafius, J. E., Nelson, W. L., and Dirks, V. A., The heritability of yield in barley as measured by early generation bulked progenies, Agron. J. 44: 253-57, 1952.

10. Jones, K. R. and Frey, K. J. Heritability percentages and degrees of dominance for quantitative characters in oats, Iowa State J. Sci. $35: 49-58,1960$.

11. Lush, J. L., Heritability of quantitative characters in farm animals, Proc. Eighth Int. Congr. Genet., Hereditas Supplement pp. 356-73, 1948.

12. Mahmud, I. and Kramer, H. H., Segregation for yield, height, and maturity following a soybean cross, Agron. J. 48: 605-09, 1951.

13. Mather, K., Biometrical Genetics, Dover Publications, Inc., New York, N.Y., 1949.

14. Robinson, H. F., Comstock, R. E., and Harvey, P. H., Estimates of heritability and the degree of dominance in corn, Agron. J. $41: 353-59,1949$.

15. - Genotypic and phenotypic correlations in corn and their implications in selection, Agron. J. 48: 282-87, 1951.

16. Swarup, V., and Sharma, B. R., Inheritance of some quantitative characters in cabbage, Ind. J. Genet. and Plant Breeding 25: 57-64, 1865.

17. Thomas, H. L., and Kernkamp, M. F., The use of heritability ratios and correlation coefficients for measuring combining ability with smooth bromegrass (Bromus inermes leyss), Agron. J. 46:553-56, 1954.

18. Wallace, A. T., Middleton, G. K., Comstock, R. E., and Robinson, H. F., Genotypic variances and covariances of six quantitative characters in oats, Agron. J. $46: 484-88,1954$.

19. Warner, J. N., A method for estimating heritability. Agron. J. 44: 427-30, 1952.

20. Weber, C. R., and Moorthy, B. R., Heritable and non-heritable relationships and variability of oil content and agronomic characters in the $F_{2}$ generation of soybean crosses, Agron. J. 44: 202-09, 1952. 